\title{
Improving the Quality of Non-Fictional Writing Skills Through Writing Information on Social Media
}

\author{
Rokhmat Basuki* \\ Indonesian Language Education Study Program, Bengkulu University \\ *Corresponding author. Email: rokhmat.bas@gmail.com
}

\begin{abstract}
This study aims to describe the learning process of Non-fictional Writing and to determine the improvement of non-fictional writing lecture achievement by using the method for non-fictional students of the Indonesian Language Education Study Program, University of Bengkulu. The research method uses classroom action research methods. Data collection techniques were using tests, interviews, and observations. The research subjects were semester IV c students of the Indonesian Literature and Language Education Study Program, Faculty of Teacher Training and Education, Bengkulu University. Data analysis techniques were carried out by data reduction, data presentation, interpretation of test analysis results, interviews, and observations, as well as making conclusions based on indicators of the success of classroom action research. The results showed that there was a change in student attitudes and behavior that was more positive. In the first cycle, students looked happy and excited in lectures. In addition, in the second cycle students became more active and enthusiastic in participating in the whole series of lectures. The lecture achievements obtained by students are in the category of increasing with satisfactory results. It was proven in the first cycle, the students' average score was 70 with details of 7 students who got very good grades or 19\%. Students with good grades amounted to 19 or 53\%. Then, students with sufficient grades were 10 or $28 \%$. Whereas in the second cycle the average score was 78.5 , with details of 12 students getting very good scores or $33 \%$, while students who got good grades were 24 students or $67 \%$.
\end{abstract}

Keywords: Learning strategies, Non-fictional writing learning, Methods non-fictional.

\section{INTRODUCTION}

The success of lecture objectives is determined by many factors, including the faculty factor in carrying out the lecture process, because lecturers can directly influence, foster and improve student intelligence and skills. For this reason, it is hoped that lecturers will have a good teaching method or model and be able to choose the appropriate lecture model and in accordance with the concepts of the courses to be delivered.

In essence, lecturing activities in higher education are a process of interaction or reciprocal relationship between lecturers and students in learning units. Lecturers as one of the components in the teaching and learning process have a very important role. Lecturers are not only delivering material, but more than that, lecturers can also be said to be the center of learning.

As regulators as well as actors in the lecture process, lecturers must be able to direct how the lecture process is carried out. Therefore, lecturers must be able to create an effective and attractive lecture so that the lecture material presented makes students interested and feels the need to study the lecture material.

Lecturers also carry a heavy duty to achieve the goals of national education, namely improving the quality of Indonesian people, whole human beings who believe and fear God Almighty, have noble character, have personality, are disciplined, work hard, are tough, responsible, independent, intelligent, and skilled, as well as physically and mentally healthy. Then, it must be able to cultivate and deepen love for the country, strengthen the national spirit and the sense of social solidarity. In line with that national education will be able to realize human development and build them selves and be responsible for national development [1]. For that, an effort is needed in order to improve the quality of education and language teaching, one of which is to choose a strategy or method of delivering lecture material in order to obtain an increase in student achievement, especially in the Non-fictional Writing Subject.

Based on observations made by researchers, students of the Indonesian Language Education Study Program, Bengkulu University during a comprehensive exam. When they were asked questions by the examining lecturer about aspects of language, more specifically non-fictional writing, many students had difficulty answering or explaining. Ironically, they seem to forget as if they have never studied or obtained the material. This can be due to the fact that lecturers in the teaching and learning process only use lectures, discussions, and / or only use existing teaching aids, and they are less varied. 
Alternative strategies, techniques, and methods of learning non-fictional writing offered to improve students' understanding of the concept of non-fictional writing are the brainstorming method (non-fictional). Thus, it is hoped that it will strengthen students' understanding of the concepts of non-fictional writing being taught. That understanding requires interest and motivation. Without interest, indicates that students do not have the motivation to learn. The notion of the brainstorming method (non-fictional) is a creativity technique, which seeks to find solutions to a particular problem by spontaneously gathering ideas from group members [2][3]. This term nonfictional was popularized by Alex F. Osborn who explained that nonfictional -is the way that teachers think laterally, helping students to get out of a routine mindset, namely by bringing up a problem to the students, then students answer or express opinions or commented so that the problem develops into a new problem, or it can be interpreted as a way to get lots of ideas from a group of people in a short time [4]. The purpose of this method is to train students' minds to formulate their opinions with good language and sentences so that a person's vocabulary and thinking skills can be trained and improved [5].

The relevant research results show that the method non-fictional can improve students 'persuasive writing skills and can improve students' critical thinking skills [6]. This research shows that the method is non-fictional proven to be able to motivate students in learning, especially in writing and critical thinking skills. It is also hoped that method non-fictional this will be able to improve students' ability in mastering the non-fictional writing subject. Non-fictional writing is a branch of linguistic science that discusses the internal elements of sentences, namely, phrases, clauses, and sentences [7]. In language learning, especially Non-fictional Writing, lecturers can simulate lectures using question bait. The question feed can be the topic of a phrase or sentence. The bait of these questions not only makes students involved in passionate non-fictional writing lectures, it can also determine how far students respond to these questions from a learning activity or how far they absorb the information presented so as to produce optimal mastery of material for students.

The strategy made concerns the problem of how to learn phrases, clauses and sentences, both in terms of function, category and role in language. Discussion about the subject, predicate, object, complement, and description, usually lies at the sentence level as an element of the sentence. The function of clause elements is determined based on formal characteristics, which is based on the intonation and behavior of the elements in a clause. Furthermore, Ramlan (1987) tates that non-fictional writing is a part or branch of linguistics that discusses the ins and outs of discourse, sentences, clauses, and phrases.

Based on the above background, the problems in this research can be formulated as follows: (1) How is the learning planning for the Non-fictional Writing Subject using the method Non-fictional, (2) How is the student achievement in the Indonesian Language Education Study Program Bengkulu University in the Academic Year 2018 / 2019 with the application of the method non-fictional in learning the Non-fictional Writing Subject?

\section{RESEARCH METHODS}

Methods method used is classroom action research. The action design was carried out in two cycles. Each cycle consists of four stages, namely the stages of research include planning, action, observations and reflection. This research data uses two kinds of data, namely qualitative data and quantitative data. The research instrument is a researcher who is assisted by a peer lecturer. Data collection using tests, interviews, and observations were made by researchers assisted by peer lecturers. The data analysis used is an interactive analysis technique, which starts with data collection, data reduction, data presentation, and conclusion. The information obtained in data collection in non-fictional writing lectures using the method non-fictional was obtained from the analysis of the results of posttests, interviews, and observation notes. Then, for the validity of the data in this study, triangulation of data sources was carried out, namely comparing the results of tests, interviews, and observations.

In this study, researchers as well as lecturers did: compile a questionnaire for learning and compile a learning program plan. The principles of action research are divided into stages of planning, implementation, observation and reflection. The three stages are carried out with a cycle model: (1) the diagnostic stage, namely the expected result from this stage is an inventory of the obstacles and difficulties experienced by students of the Indonesian Language Education Study Program, Faculty of Teacher Training and Education, University of Bengkulu, in learning Non-fictional Writing, who must try to obtain opportunity or event in order to remember the ins and outs of Nonfictional Writing. Based on the description above, the action hypothesis can be formulated as follows: "With the implementation of the learning strategy of the Non-fictional Writing course using the Nonfictional method, the quality of lectures in the Nonfictional Writing course of Indonesian Language Education study program students, Unib. (2) The therapeutic stage, namely: Based on the results of the clarification and discussion between the researcher, who is also a lecturer in the Non- 
fictional Writing course, and the partner lecturer in the Non-fictional Writing course, then in the next stage, the expected result is that students are able to understand various details. Non-fictional writing, including understanding the language characteristics of non-fictional writing was using the non-fictional method. This step is intended to develop students' skills in learning non-fictional writing. For this reason, the implementation of the design and preparation of the stages of learning for the Non-fictional Writing course is carried out together with students and closely monitored by partner researchers and lecturers. (3) The rediagnostic or reflection stage, namely: based on the results of observation and reflection, it is hoped that at this stage the lecturers can jointly evaluate the results of the improvements from the therapeutic stage, considering that in the previous stage it was possible that students still had many difficulties in applying this non-fictional method. Then, based on the results of the improved evaluation, the action hypothesis needs to be verified, and the unresolved problem is specified and the cause is re-examined. After that the action hypothesis needs to be reformulated based on the re-diagnostic results, and. 4) The re-therapy stage, namely: based on the results of the re-diagnostic or reflection above, then at this stage the expected results of the lecturers and students can jointly design a re-improvement, namely the design and preparation of the non-fictional writing lecture stage with the non-fictional method. . Repairs need to be carefully monitored by partner researchers and lecturers; (5) and so on.

The action cycle is repeated again until a better non-fictional writing learning strategy is found, and the ability of the lecturer to design, compile and carry out the stages of learning with a learning strategy using the non-fictional method. It is emphasized by Kemmis \& Mc. Taggart [8], that the first cycle of the action research process begins with initial identification, fact-finding, and analysis to find general research problems, followed by the implementation of action, observation, and reflection (reflection, thinking, and evaluation). . In the second cycle, general problems were corrected with a more focused planning, followed by implementing actions, observations, and reflections. In the third cycle, the fourth cycle based on the results of the reflection determined the formulation of the problem in a focused manner with focused action planning, followed by the implementation of research, observation and reflection. The results of reflection are ultimately oriented toward possible practical impacts for classroom learning.

In simple terms, this research will refer to the concept of classroom action research as conducted by Suyatno [9]. The concept of action in this study is as follows: (1) Initial interviews were conducted with lecturers and students to determine action. Interviews were conducted to determine the initial conditions of students. (2) Questionnaires are supporting data used to collect information related to student responses or responses to the application of cooperative learning. (3) Observations were carried out to obtain data on students' thinking abilities which consisted of several descriptors during the learning process. These observations were carried out using a compiled observation sheet. 2 observers carried out the observation: (1) the test was carried out at the end of each cycle, this was intended to measure the results obtained by students after giving the action. The test takes the form of multiple choices so that a lot of material is covered; (2) field notes are used to complement the research data so that it is hoped that all data that are not included in the observation can be collected in this study.

This research will be conducted in 2 cycles. Each cycle consists of planning, acting, implementing actions, observing, reflecting. (1) Before carrying out an action it is necessary to make preparations. Activities at this stage include: (a) preparation of RPS with a learning model planned in the CAR; (b) preparation of student problem sheets / worksheets according to the course indicators to be achieved; (c) making test questions that will be held to determine the results of students' Non-fictional Writing learning; (d) forming heterogeneous groups, both in terms of academic ability, gender and ethnicity; (e) provide an explanation to students about the technique of implementing the learning model to be implemented. (2) Implementation of actions: (a) carry out activities in accordance with the learning plan that has been made. In conducting research, the lecturer becomes a facilitator during learning, and students are guided to learn non-fictional writing using the method non-fictional. The steps taken are adjusting to the learning scenario, (b) Closing activities. At the end of the implementation of learning in each cycle, the lecturer gives a written test to evaluate the results of students' NonFunctional Writing lectures, during the learning process. (1) Observations are made during the learning process by collaborating in its implementation. (2) At this stage data analysis is carried out. The results of existing data analysis are used to evaluate the processes and results to be achieved. Reflection is intended as an effort to examine what has or has not happened, what was produced, why it happened and what needs to be done next.

The results of reflection are used to determine the next step in an effort to produce improvements in cycle II. The activities of cycle II are basically the same as cycle I, except that the planning of activities is based on the results of reflection in cycle I so that it is more directed at 
improving the implementation of cycle I. The quality of students' non-fictional writing learning is analyzed by rubric

Then to find out the increase in thinking ability scores, the questions and answers that have been assessed by a rubric in cycle I are compared with the questions and answers that have been assessed with a rubric in cycle II.

The formula for finding the classical score of students' learning ability Non-fictional Writing Real score X 4 Maximum score

Description:

Real : $\begin{aligned} & \text { scoretotal score obtained by } \\ & \text { students }\end{aligned}$

Maximum : scoreTotal score that should be obtained by students

Number $4 \quad$ : Maximum score of each answer

Learning outcomes in the cognitive aspect of results The test is analyzed by using evaluation analysis techniques to determine student learning completeness. The method is to analyze the results of the formative test using learning completeness criteria. Individually, students are considered to have studied thoroughly if their absorption capacity reaches $65 \%$. As a group, it is considered complete if it has reached $85 \%$ of the number of students who reach a minimum absorption capacity of $65 \%$. It is hoped that with the learning strategy in the Non-fictional Writing course using the Nonfictional method, the learning outcomes of students in the Indonesian Language Education Study Program, Bengkulu University can increase.

\section{RESULTS AND DISCUSSION}

Results obtained from interview data, observations and tests on the application of the method non-fictional in teaching non-fictional writing in the Indonesian Language Education Study Program, University of Bengkulu, can be informed that: (1) the learning outcomes of Nonfixed Writing with the non-fictional method are followed by changes in attitudes and more positive student behavior. In the first cycle the students looked happy and excited about learning. In addition, students are increasingly active and enthusiastic in participating in all series of lessons. (2) The results of non-fictional writing lectures increase with satisfactory results. It was proven in the first cycle, the student's average score was 70 (seventy), with 7 (seven) students getting very good scores or $19 \%$. Students with good scores of 19 (nineteen) or $53 \%$, and students with sufficient grades of 10 (ten) or $28 \%$. Then, in the second cycle the average score achieved was 78.5 (seventy eight point five) with details of 12 (twelve) students getting either once or $33 \%$, while students who got good grades were 24 (twenty four) students or $67 \%$.

The classroom action research carried out showed that the strategy of increasing student learning achievement of Non-fictional Writing in the Indonesian Language Education Study Program, University of Bengkulu with the method was non-fictional able to increase student motivation to learn and was able to improve students' ability to understand the concept of nonfictional writing. This shows that the method nonfictional can improve students' critical thinking skills when learning so that they are able to express their ideas in writing assignments about the concept of non-fictional writing. This is in accordance with the results of previous research conducted by Firdaus, et al., (2019) and Utami (2015) that the method is non-fictional able to improve students' critical thinking and writing skills.

This study consisted of 2 cycles. In the first cycle, all class $\mathrm{C}$ Semester IV students attended. The beginning of the learning action, the lecturer began by delivering the non-fictional writing material question instrument which was considered the most difficult to memorize and understand by students. The results show that the average semester IV C students are confused in determining related sentences in their form and meaning. Therefore, this research was conducted with the intention that students of the Indonesian Language Education Study Program could have a technique to understand and understand non-fictional writing in Indonesian, whether the sentence consists of one word or several words. Thus, students have provisions to improve their learning ability in the aspects of Non-Fictional Writing in the future after they become teachers. Before this classroom action research was carried out, first the researcher and partner lecturers in the Indonesian Language Nonfictional Writing Subject prepared a good action plan, such as learning materials, learning scenarios, and question instruments that would be needed in implementing the action.

The pre-research began at the first meeting, namely at GKB IV room 17 in semester IV class C. After greeting and checking the attendance of students, the research lecturer who was accompanied by partner lecturers and peers conducted an assessment of the students' mastery of non-fictional writing in Indonesian about definitions and understanding Write non-fictional, phrases, and sentence details they know. It turned out that quite a number of students stated that they forgot, did not know, and some even stated that they had just heard these terms. Of course, this situation is quite worrying so that in order to obtain accurate data the lecturer conducts initial tests related to the Indonesian Language Non-fictional Writing material. In this case students are asked to answer questions that have been prepared by the 
lecturer. It was quite a "rowdy" atmosphere in the classroom at that time, because students did not expect at all they would get a question like that. After sufficient time the lecturer then asked the students to collect the completed observation sheets to the front of the class. Then an assessment is carried out. As for the results, it is very concerning. The average student answers are still incomplete or incomplete. In this case the lecturer provides reinforcement that these students must have the knowledge to 'mark' various aspects of nonfictional writing, because it can help students understand rather than just saying a lot of words. Moreover, after they finish their studies from this study program, they will later become Indonesian language teachers, who must equip themselves with a lot of understanding of various definitions of nonfictional writing.

The implementation of the first cycle of action, (1) the lecturer checks the student attendance list, (2) the lecturer gives apperception to students to draw their attention to the learning material to be delivered, (3) the students listen to learning material about "phrases" and "details" in Indonesian, (3) the lecturer explains a technique to know and understand more quickly about the two materials above to students.

The technique described is the model, a nonfictional tool in the form of questioning that can be used by students to remember and learn the information they have just received, (4) students seem quite enthusiastic about listening to the lecturers' explanation questions about it, because previous students found it too difficult to distinguish and memorize the materials. Write the Non-fictional. According to the students, the material is like freedom of thought, so that if one is understood, then their other expectations can be understood. In this case the lecturer provides reinforcement that the students when they become Indonesian language teachers have mastered and equipped themselves with simple techniques, (5) after assessing that the students understand the method above, the lecturer asks students to start expressing the opinions they have made. and write the "phrase" material according to the agreement above. The lecturer shows the brainstorming procedure to be used in learning non-fictional writing to students, namely: (1) reading the complete "phrase" material; (2) pay attention to the core that must be learned. The lecturer gives time to students to read and then describes something that has been prepared for each material that has been determined above using a brainstorming model. Students are expected to be able to thoroughly discuss the theme.

When the activity was carried out, the students' behavior and attitudes varied. Some were serious, some looked at their friends from side to side, some showed a confused expression even though at first they were hesitant to reveal the ideas they had mastered. Furthermore, after a predetermined time, students are asked to reread the material that has been studied and reveal it again so that there is no misunderstanding. Furthermore, students must conclude together with the lecturer what they have discussed. (6) Furthermore, the lecturer explains briefly to each student, and the students must recite what they have concluded.

After the implementation of cycle $I$ is complete, researchers and peers meet to reflect on the activities of the Indonesian Language Nonfictional Writing lecture that have been taking place. Reflection is carried out by looking at the results of observation notes from researchers with partner lecturers, as well as notes from peers, and based on discussion of the results of actions that have been taken in cycle I, then the results are described.

From the notes and discussion, it was revealed several things that were still the weaknesses of this non-fictional implementation, in addition to the various advantages and successes of the implementation of the special Non-fictional Writing learning material on "phrases" and "details" in Indonesian using the fictional method Non-. The following notes and inputs can be conveyed: (1) students still have doubts and insecurities that they can quickly understand the above material in a shorter time; (2) students who are less proactive in attending this lecture tend to have difficulty developing non-fiction on the two materials that have been agreed upon above, even though they are simple, but must be examined systematically, not arbitrarily. Thus, we will be able to feel the maximum results of this nonfictional method. (3) Lecturers seem a little overwhelmed in accompanying and motivating students because there is no experience and description of lecture results using the non-fictional method. Students scramble to get the lecturers' attention on their opportunity, so that the lecturer when setting the rhythm is not optimal. It needs to be refined so that the results can be better. (4) In presenting problems or knowledge to students, the lecturer looks not fully ready because the expressions or utterances put forward by the students are still very plain and simple. (5) The lecture techniques and materials specially prepared by the lecturer are not yet perfect. Then, (6) it is necessary to strive for more creative behavior, both from lecturers and students who take the Indonesian Language Non-fictional Writing Subject. In the first cycle of research, the learning outcomes of Indonesian non-fictional writing were obtained using the method non-fictional, students were proven in the first cycle, the students' average score was 70 (seventy) with 7 (seven) students having a very good score or $19 \%$. Students with 
good scores of 19 (nineteen) or 53\%. And students with sufficient grades of 10 (ten) or $28 \%$.

Table 1. Learning Outcomes of Cycle I

\begin{tabular}{|c|c|c|c|c|}
\hline No. & $\begin{array}{c}\text { Averag } \\
\text { e Value }\end{array}$ & $\begin{array}{c}\text { Absortio } \\
\mathrm{n}\end{array}$ & $\begin{array}{c}\text { KK } \\
\mathrm{M}\end{array}$ & $\begin{array}{c}\text { Completenes } \\
\text { s (\%) }\end{array}$ \\
\hline 1 & 70 & $70 \%$ & 70 & $89 \%$ \\
\hline
\end{tabular}

The results of the non-fictional writing lecture using the method non-fictional were followed by changes in student attitudes and behavior that were more positive. In the first cycle the students seemed less happy and less enthusiastic in learning. In addition, students are increasingly active and enthusiastic in participating in all series of lessons. From the results of research on language learning in the field of Indonesian Non-fictional Writing with the method nonfictional, the students above, it can be concluded that the ability of students to understand phrases, and recognize the types of phrases, clauses and sentences in Indonesian has increased after participating in the learning process with this nonfictional, and student behavior changes to be more open and more enthusiastic about learning about linguistic aspects, as well as being more positive. Implementation of cycle 2 actions.

Before Cycle 2 classroom action research was carried out, the lecturer asked students whether they felt they were helped in understanding language materials, especially the non-fictional aspects of writing when using non-fictional learning as was assigned by the lecturer last week. Student answers were quite positive, because according to their explanation the method can help learn to remember a material in a more focused way and arise a sense of empathy for a material. Of course, the students' statements become their own capital and motivation to be able to carry out this second cycle more seriously and carefully. The students of the Indonesian Language and Literature Education Study Program, Department of Language and Arts Education, Bengkulu University, who were the subjects of this classroom action research, numbered 36 people, consisting of 31 women and 5 men who were divided into 2 (two) groups. After everything is ready, class actions are carried out, in the form of (1) The lecturer checks the student attendance list. Then the lecturer gave apperception to the students and repeated the material that had been delivered at the previous week's meeting, namely about phrases, clauses and sentences. (2) The lecturer then invites students to agree on the second material to be conveyed in this second cycle of action. Topics agreed upon by students because they could be confusing were phrases, clauses, and sentences Therefore, the material is put into the form of questions addressed to each student. (3) The lecturer explains to students the phrases, clauses and sentences in Indonesian and the students respond with a brainstorming model. (4) Students increasingly understand the opinions of each student about phrases, clauses and sentences. They look more serious and enthusiastic. Unlike the conditions at the time of the first cycle of action, in this action they were seen to be able to concentrate in responding to the lecturers' questions, they did not see the confused faces of the students anymore, even though the time given to solve the problem was also limited. In this case, the lecturer provides reinforcement that thoughts about the material can be developed for other fields. (5) In the final activity, students together with the lecturer review how to provide brainstorming with the hope that this method can help students enrich and broaden their understanding of other material, so that it becomes their provision, especially after becoming a teacher later. Then, (6) After the 120 minutes of lecture time has passed, the lecturer ends the activity by saying hello and leaving the classroom.

After the implementation of the second cycle of action ends according to the plan, the research lecturers and partner lecturers meet to reflect on the teaching and learning activities that have been taking place. Based on the observations made, it turns out that the shortcomings and weaknesses contained in the action of cycle I can be corrected and the action is optimized so that it allows the action of cycle II to run better with increased results, such as: 1) the class atmosphere becomes more conducive, students No longer feel inferior or confused about having to complete one by one the Non-fictional Writing materials they made in a shorter time or time. Each of them is able to concentrate on his thoughts. (2) Students have high enthusiasm and interest in learning other nonfictional writing materials using the method nonfictional writing. They realize that if the language learning technique is carried out in a varied, innovative, happy, and simple way, the learning outcomes will be better, not boring or bored. Even learning Indonesian is a favorite subject. Then, (3) the lecturer also highly appreciated the results of the students' efforts to develop the Non-fictional Writing learning technique using the method Nonfictional, even though it was no longer implemented in the classroom. The desire to broaden their thinking horizons for various other subjects becomes their motivation which they have not thought about so far. It turns out that techniques non-fictional can be a fast, effective, but not boring learning model. Thus, there will be no more complaints that express objections or are overwhelmed by studying the field of linguistics or language as so far.

Based on the results of the action in the 2 nd cycle above, after an agreement was made between 
the research lecturers and the partner lecturers, in this second cycle only used 1 (one) discussion topic, to see if there was a difference in the results of learning completeness in Indonesian Nonfictional Writing. , be better or even decrease compared to the results in the action cycle I. In this second cycle meeting, there were 36 students attending, consisting of 31 women and 5 men producing: In the second cycle it resulted in $100 \%$ or 36 students were categorized as complete, while the classical average score reached 78.5. Thus, there was an increase in categories from cycle I to cycle II. The improvement of the results of nonfictional writing in Indonesian using non-fictional techniques was also followed by changes in student attitudes and behavior that were more positive. In the second cycle students looked happy and excited in learning. In addition, students are increasingly active and enthusiastic in participating in a whole series of lectures.

The results of research on language learning in the field of Indonesian shows non-fictional writing with the method non-fictional. Thus it can be concluded that the ability of students to understand Indonesian phrases, clauses and sentences has increased after following the learning process using method non-fictional this, and student behavior has changed to be more open and more enthusiastic about learning aspects of language, as well as becoming more positive. In implementation, students have the agility in expressing opinions about the intricacies of writing non-fictional language with materials that exist in life in the community. Theoretically, students already know about the intricacies of non-fictional writing and the products it produces. Likewise, the diversity of non-fictional writing is concerning the use of language in social life.

The results of observations can be seen first that students always pay attention to lectures from the lecturer who teaches the course, second, namely enthusiasm and enthusiasm in attending lectures, interest with the method non-fictional. Students answer lecturer questions with a brainstorming model. Students work together in groups. Students study the material seriously and answer competency test questions and evaluation questions seriously. Questionnaire of student responses to non-fictional writing lectures was given to 36 students. The results of the student questionnaire responses to lectures using media rather than lectures alone gave responses in the strongly agree category (76\%) and students who gave responses in the agree category $(34 \%)$. The lecture implementation uses the method non-fictional, students who give responses in the category of strongly agree (68\%), and those who give responses in the category of agree $(32 \%)$. The display quality is in the method non-fictional, giving responses in the category of strongly agree
(62\%) and giving responses in the category of agreeing (38\%).

On the effect of using the method nonfictional, students gave responses in the category of strongly agree $(70 \%)$, and students gave responses in the good or agreed category (30\%). The results of this questionnaire did not find students who gave poor or bad responses. Evaluation is given in the form of a test, after being corrected, the student learning outcomes show that of the 36 samples proven in the first cycle, the student's average score is 70 (seventy) with 7 (seven) students having a very good score or $19 \%$. Students with good scores of 19 (nineteen) or 53\%.Then, students with a sufficient grade of 10 (ten) or $28 \%$. Furthermore, in the second cycle the results of student scores averaged 78.5 (seventy-eight point five).

Table 2. Learning Outcomes of Cycle II

\begin{tabular}{|c|c|c|c|c|}
\hline $\begin{array}{c}\mathrm{N} \\
\mathrm{o}\end{array}$ & $\begin{array}{c}\text { Averag } \\
\text { e Value }\end{array}$ & $\begin{array}{c}\text { Absortio } \\
\mathrm{n}\end{array}$ & $\begin{array}{c}\text { Averag } \\
\text { e class }\end{array}$ & $\begin{array}{c}\text { Completenes } \\
\mathrm{s}(\%)\end{array}$ \\
\hline 1 & 78.5 & $78.5 \%$ & 70 & $100 \%$ \\
\hline
\end{tabular}

The results of the evaluation showed that $56 \%$ of the students scored in the very good category and $46 \%$ of the students were in the good category, and there were no students who scored in the sufficient, poor or failed category.

\section{CONCLUSION}

Based on the results of the research and discussion, it can be concluded that: (1) the learning outcomes of non-fictional writing with the method non-fictional were followed by changes in student attitudes and behavior that were more positive. In the first cycle the students looked happy and excited about learning. In addition, students are increasingly active and enthusiastic in participating in all series of lessons. (2) The results of non-fictional writing lectures increase with satisfactory results. It was proven in the first cycle, the student's average score was 70 (seventy), with 7 (seven) students getting very good scores or $19 \%$. Students with good scores were 19 (nineteen) or $53 \%$. Students with sufficient grades amounted to 10 (ten) or $28 \%$. In the second cycle, the average score achieved was 78.5 (seventy eight point five) with details of 12 (twelve) students getting either once or $33 \%$, while students who got good grades were 24 (twenty four) students or $67 \%$.

\section{REFERENCES}

[1] Depdikbud. (1999). Instructions for the Implementation of the Teaching and Learning 
Process. Jakarta: Balai. Pustaka

[2] Firdaus, A., Wahdah Humaira, H., \&Firdaus, A. (2019). The Effect of Non-fictional Methods on Persuasive Writing of Class VIII Students of SMPN 15 Sukabumi. Basastra, 8(2), 142. doi: 10.24114 / bss.v8i2.14467

[3] Amin, D. (2017). Application of Brainstorming Method (Non-fictional) to Increase the Ability to Express Student Opinions. Journal of Historical Education, 5(2), 1. doi: 10.21009 / jps.052.01

[4] Roestiyah, NK (2001). Teaching and Learning Strategies. Jakarta: Rineka Cipta. Sudaryanto. (2015). Improved Mastery of Indonesian Language Non-fictional Writing Concepts through the Application of Concept Map Media in the Department of Indonesian Language and Literature Education. Litera, 6(1). doi: 10.21831 / ltr.v6i1.6814
[5] Indihadi, D. (2018). Learning Writing Based "Non-fictional." Indonesian Journal of Primary Education, 2(2), 91. doi: 10.17509 / ijpe.v2i2.15172

[6] Utami, D. (2015). The Effect of Non-fictional Methods on Critical Thinking Ability in Science Learning. Journal of Basic Education, 6(2), 232. doi: 10.21009 / jpd.062.05

[7] Noermanzah \& Friantary, H. (2019). Development of Competency-Based Poetry Learning Materials for Class X High Schools. International Journal of Recent Technology and Engineering, 8(4).

[8] Kemmis, S. \&Mc.Taggart, R. (1988). The Action Research Planner. Victoria: Deakin University Press.

[9] Suyatno. (2009). Exploring Innovative Learning. Sidoarjo: Masmedia Buana Pustaka. 